\title{
NEW SCULPTURE OF THE ERA OF EARLY NOMADS FROM TURGAY
}

(C) 2017

Bazarbayeva Galiya Appazovna, candidate of historical sciences, leading researcher of Prehistoric Department Jumabekova Gulnara Sainovna, candidate of historical sciences, leading researcher of Prehistoric Department A.Kh. Margulan Institute of Archaeology (Almaty, Republic of Kazakhstan)

Abstract. The paper introduces a stone sculpture of the era of early nomads from Turgay into scientific use. This region is the western wing of Saryarka. In 2015-2016 the monuments of the Tasmola culture were researched. The finding is a rather rare case of the location of the statue in the mound complex with stone ridges. Field researches of the construction with a statue have shown an unusual character of its site. Laconism in the transfer of the anthropomorphic image finds parallels in the sculptures of Central Kazakhstan of early nomads. Sculptures from Central Kazakhstan are similar to the sculptures of the Northern Black Sea coast and the South Ural steppes based on their purpose and pictorial techniques. It is assumed that the aspect of military glory, traced in medieval sculptures, originated in the era of the early nomads, and the evidences are the findings of stele and stone sculptures.

Keywords: Turgay; Central Kazakhstan; early iron age; Tasmola culture; Scythian; mound; field researches; medieval; nomads; statue; sculpture; kurgans with stone ridges; excavations; complex; fence; constructive element; funeral rite; bodily attributes; stelae; anthropomorphic image; signs.

УДК 94 (367) : $929.5 \ll 15 »$

\section{КАШИНСКИЕ КНЯЗЬЯ В 60-Е - НАЧ. 80-Х ГОДОВ ХIV ВЕКА}

(C) 2017
Абуков Сергей Навильевич, кандидат исторических наук, старший преподаватель
кафедры историографии, источниковедения, археологии и методики преподавания истории Донецкий национальный университет (2. Донецик, Донецикая Народная Республика)

\begin{abstract}
Аннотащия. В статье автор исследует значение Кашина как крупного центра Тверского княжества в период правления Василия Михайловича и противостояния Москвы и Твери, неустойчивую позицию кашинских князей, обусловленную борьбой партий в среде местной правящей элиты, оказавшейся между двумя центрами силы. В результате часть элиты продолжала ориентироваться на Тверь, в то время как другая отдавала предпочтение Москве. Последняя позиция взяла верх, что обусловило отказ кашинского князя от договора с Михаилом Александровичем и его участие в походе на Тверь в 1375 году. Особое внимание в статье уделено росту местного сепаратизма, судьбе Кашинского княжества по договору 1375 г., закрепившему выход его изпод верховной власти Твери, а также краткому периоду его формальной независимости и обстоятельствам его возвращения под власть Твери в 1382 г.
\end{abstract}

Также анализируется влияние родственных связей кашинских князей, в первую очередь брак кашинского князя Михаила Васильевича и московской княжны Василисы Семеновны, причины, обстоятельства и значение этого брака в свете московско-тверских отношений в 60-80-е гг. XIV в. в общем контексте брачных союзов двух ведущих княжеств Северо-Восточной Руси.

Ключевые слова: Василий Михайлович; Михаил Васильевич; Василий Михайлович (II); Михаил Александрович; Семен Гордый; Мария Александровна; Дмитрий Донской; Кашин; Москва; Тверь; князь; брак; родственные связи; конфликт; XIV век.

Соперничество Москвы и Твери стало одним из ключевых событий борьбы за лидерство в СевероВосточной Руси в первой четверти XIV в. Фактически именно эти два центра, возглавляемые правящими линиями потомков Ярослава Всеволодовича, явились теми княжествами, которые могли возглавить процесс объединения русских земель. Во второй половине века характер борьбы между ними изменился. Тверь уже не имела возможности самостоятельно противостоять Москве, вынужденно опираясь на внешние силы, что во многом предопределило ее окончательное поражение. Часто это противостояние отличалось драматизмом и ожесточением сторон. Однако московско-тверские отношения были сложными и многогранными. Времена открытых конфликтов и войн сменялись годами относительно мирного существования и союзничества. Одним из показательных и важных форм взаимодействия двух княжеских домов были династические браки, ставшие существенным фактором эпохи феодализма. Это был своеобразный маркер, демонстрирующий намерения и планы сторон. В этом контексте обращает на себя внимание брак дочери Семена Гордого и сына великого князя тверского Василия Михайловича Кашинского, имевший далеко идущие последствия для московко-тверских отношений в период возобновления московко-тверской войны.

Однако особого внимания заслуживают сами кашинские князья в этот драматичный исторический период и их княжество, а также краткие годы существования формально независимого Кашинского княжества, а также обстоятельства, в результате которых Кашин вернулся под власть Твери. Изучение круга этих вопросов позволяют глубже понять всю сложность и противоречивость процесса возвышения Москвы и истории правящих феодальных элит Северо-Восточной Руси. Несмотря на очевидную значимость проблемы, она не получила пристального внимания историков.

События, связанные с Кашином в этот период, упоминали крупные историки, исследовавшие этот период, однако в общем контексте истории Руси [1- 
3]. Пристальному рассмотрению истории Тверского княжества мы обязаны немногим историкам, высказавшим отдельные ценные замечания по Кашину и его князьям [4-6]. На родственные связи и уточнение генеалогических позиций было направлено внимание генеалогов $[7 ; 8]$. Из специальных работ, посвященных кашинским князьям, следует назвать работу А.Д. Иноземцева, написанную еще в 70-е гг. XIX в., когда не был известен весь круг важнейших источников [9]. Что касается источников, то основная информацию дают древнерусские летописи, сохранившие тверское летописание, дошедшие немногочисленные правовые акты.

История кашинских князей начинается с четвертого сына убитого в Орде в 1318 г. Михаила Ярославича Василия, ставшего удельным кашинским князем, а после смерти старших братьев и борьбы с племянником Всеволодом занявшим великокняжеский тверской стол. Кашин, хотя и достался самому младшему из Михайловичей, тем не менее по своему значению становится вторым городом Тверской земли. Важнейшим событием, оказавшим заметное влияние на дальнейший ход событий, следует считать летописное известие 1350/1 г. Рогожского летописца: «Тое же зимы князь великїи Семенъ Иванович[ь] выдаль дчерь свою во Тферь за князя Михаила Васильевича» [10, стб. 60]. За 3 года перед этим (1347 г.) сам Семен Гордый женился на двоюродной сестре будущего зятя [10, стб. 57]. В обоих браках был очевидный политический расчет. Фактически через свою третью жену Марию Тверскую и дочь Семен Гордый создавал два направления влияния на Тверь через родственные союзы с Александровичами и Василием Михайловичем - в середине XIV в. ведущими линиями тверских князей, которые откровенно не ладили между собой. Однако и кашинские князья рассчитывали, «уравнявшись браками», на поддержку могущественной Москвы против своих врагов. В идеале Василий Михайлович был не прочь оставить Тверь за своей линией [6, с. 176]. Если первое время московские власти оказывали поддержку холмскому князю Всеволоду Александровичу, то с приходом к власти в Москве брата умершего от чумы Семена Гордого Ивана Красного стали переориентироваться на кашинских князей в их внутритверском конфликте. При девере вдова Гордого уже не имела никакого влияния, к тому же лишившись завещанного мужем Коломенско-Можайского удела. Историк Э. Клюг не исключил связь между территориальными потерями вдовствующей княгини и изменением симпатий к Александровичам в Москве [6, c. 169]. Видимо, правящая московская элита рассматривала Всеволода как потенциально опасную фигуру.

Тверь даже оказывала Москве поддержку в трудную годину. В этом контексте любопытно татищевское известие о событиях в Орде в период соперничества за великокняжеский титул. По его сообщению, права малолетнего Дмитрия Московского перед ханом Амуратом поддерживали князья тверские и ростовские [1, с. 113]. Соловьев видел причину их активности в пользу Москвы в желении иметь великим князем владимирским неопытного и слабого ребенка [3, с. 256]. Кажется, больше они были обеспокоены тем, что ослабление Москвы негативно отразится на его собственном положении в соперничестве с их родственниками. Если это сообщение верное, то в случае с Тверью это были явно не Александровичи, а Василий Михайлович, перманентно конфликтующий с непослушными и амбициозными племянниками, опиравшимися на Литву. Тот же Татищев называет ранее посланцем Дмитрия Московского к хану Наурусу некоего Василия Михайловича, который просил для него ярлык на Владимир, но не добился успеха $[1$, c. 110]. Найти в это время иное лицо с таким именем и отчеством непросто.

В связи с князем Василием Кашинским необходимо обратиться к еще одному браку, а именно к сообщению Рогожского летописца 1362 г. о выдаче им своей дочери за моложского князя (тогда второй по значению стол Ярославского княжества) [10, стб. 73]. Речь, видимо, идет о моложском князе Федоре Михайловиче. Как видно, кашинско-тверские и моложско-ярославские князья были заинтересованы в укреплении отношений путем заключения родственного союза.

Кто из двух сыновей Василия Михайловича: Василий или Михаил был оставлен в Кашине, пока их отец сидел на тверском столе, не ясно. А.В. Экземплярский считал, что это был Василий Васильевич, умерший бездетным в Кашине осенью 1363 г. [7, с. 526]. А.Е. Пресняков не высказался определенно по этому вопросу, согласившись с тем, «что в. кн. Василий держал вотчинный Кашин сыновьями» [5, c. 397]. Любопытно, что в это время кашинские волости начинают в документах отделяться от тверских $[11$, c. 152]. В дальнейшем как местный князь упоминается уже Михаил Васильевич. Вместе с отцом он поддерживал его в конфликте с микулинским, а затем тверским князем Михаилом Александровичем и в организации привлечения тверского епископа Василия к ответственности за судебное решение в пользу соперника по вопросу наследования удела умершего от чумы князя Семена Константиновича [10, стб. 84-85].

После потери непопулярным Василием Михайловичем Твери сын Михаил уступил отцу Кашин, но продолжает упоминаться как особая фигура. Имел ли он отдельный собый удел - не ясно. Не останавливаясь на перипетиях конфликта дяди и племянника, отметим, что усобица внутри семьи тверских князей была только на руку Москве, вставшей на сторону Василия Кашинского и принявшей участие в опустошении владений Михаила Александровича. В 1367 г. переговорщиком с последним выступил от имени отца Михаил Васильевич. Вскоре Василий Михайлович умер в Кашине (24 июля 1368 г.) [10, стб. 87-88].

После смерти отца его единственный сын Михаил Васильевич стал полноправным князем на кашинском столе. Изменились цели кашинского князя. Теперь главной задачей для него стало отстаивание своей самостоятельности от двоюродного брата Михаила Александровича - великого князя тверского. Не менее важно, что Кашинское удельное княжество продолжает обособляться. В истории с мощами, которые потревожил Михаил Васильевич в Богородиц- 
ком монастыре Кашина, и поразившей его и княгиню тяжкой болезни обращает на себя внимание явный элемент осуждения, возможно, не просто за святотатство, а в более широком политическом контексте. И хотя князь выздоровел, но его жена умерла 20 апреля следующего 1369 г. [10, стб. 90-91].

С началом обострения отношений между Михаилом Тверским и Дмитрием Московским Михаил Кашинский оказался между двумя центрами силы. В 1369 г. после первого болезненного нашествия Ольгерда на Москву, мы видим его уже у митрополита с жалобой на тверского епископа Василия [12, с. 12]. Едва ли этот шаг мог быть дружественным по отношению к Михаилу Тверскому, однако не видно прямого разрыва. В 1371 г. кашинский князь, о котором некоторое время не было слышно и позиция которого колебалась в зависимости от обстоятельств, перешел на сторону Дмитрия Московского, сложив крестное целование Михаилу Тверскому. Говорится о мирном договоре, заключенном им с московским князем, - знак того, что ранее они были противниками [12, с. 17]. Ответ тверского князя не заставил себя долго ждать: по его наущению литовская рать напала на Кашин, взяв откуп с города, и разорила волости. Как сказано далее: «Михайло Александровичь Тверскій брата своего князя Михаила Васильевича Кашинскаго приневоливъ свою волю и крестнымъ целовавніемъ утверди» [12, с. 17-18]. Однако через год мечущийся кашинский князь, предварительно разовав договор с Михаилом, отправился сначала в Москву, а затем в Орду. Цель поездки не сообщается, но визит был явно направлен против великого князя тверского. Кажется, результат поездки не был достигнут. Вскоре после возвращения кашинский князь умер (1373 г.). [12, с. 19]. Вообще, судя по смертности среди тверской элиты, княжество в 1372 1373 гг. посетила очередная эпидемия, унесшая жизни князей Михаила Кашинского и Еремея Константиновиа, епископа Василия [10, стб. 104-105].

Преемником Михаила Васильевича стал его сын и внук Семена Гордого по матери Василий, который, оставшись сиротой, и как видно малолетним, находился под опекой бабки, княгини Елены Ивановны, которая поспешила вернуть Кашин в лоно Твери. Михаил Кашинский прибыл в Тверь к двоюродному брату «с челобитьемъ и вдашася въ волю его» $[12$, c. 20]. Не исключено, что княгиня, урожденная брянская княжна, выражала не сколько протверские, сколько пролитовские настроения части кашинской элиты. Брянск находился во враждебном Москве стане, и Дмитрий посылал на него войска [12, с. 12]. Вообще, княгиня представляется женщиной, активно вмешивавшейся в политику еще при своем муже [6, c. 176]. Возможно, если бы жива мать князя, ситуация сразу развивалась бы по другому сценарию. Но и кашинские бояре, как сказано, также поддержали такой шаг. Постоянные колебания кашинских князей между Москвой и Тверью, за спиной которого стоял Ольгерд Литовский, показывают всю сложность и неопределенность борьбы. Теперь все тверские князья оказались «в одиначестве» под эгидой великого князя тверского. Однако и на этот раз протверской поворот Кашина оказался недолгим. Здесь вновь бе- рут верх промосковские силы, толкнувшие Василия Михайловича в объятия его московской родни. Как сказано в Никоновской летописи под 1374 г., кашинский князь «побежаль съ Твери на Москву къ великому князю Дмитрею Ивановичу» [12, с. 21]. Во главе своей рати Василий принял участие в эпическом походе русских князей на Тверь, завершившемся поражением Михаила Тверского. В летописях отмечается действия кашинцев в разорении собственно тверских волостей [13, с. 190]. Очевидно, имело место дальнейшее усиление центробежных тенденций внутри Тверского княжества и обособление Кашина как отдельного образования.

Такое положение дел было закреплено в московско-тверском договоре 1375 г., зафиксировавшем тяжелое поражение Михаила Тверского, где оговаривается независимость Кашинского княжества. Оба тверских центра были поставлены в равные условия, весьма выгодные Москве разделением Тверской земли. Михаил Тверской больше не был сюзереном местного князя Василия Михайловича, который теперь не должен был доставлять ордынскую дань в Тверь [14, с. 26]. Более того, Дмитрий выступил гарантом и защитником независимости княжества своего двоюродного племянника («А в Кашин ти ся не въступати, и что потягло х Кашину, ведаеть то отчичь кн(я)зь Василеи. Ни выходом не надобе тобе ко Тфери Кашину тянути. А его ти не обидети. А имеш(ь) его обидети, мне его оть тобе боронити. А что еси изъимал бояр и слуг и людеи кашинских, да подавал на поруку, с тех ти порука свести, а их отпустити, а кому чего на них искати, ино тому суд») [14, c. 26]. Таким образом Москве удалось впервые расчленить Великое княжество Тверское, тем самым значительно ослабив его.

Кашинское княжество в новом качестве просуществовало под прикрытием Москвы почти 7 лет. Об этом периоде сохранилось весьма мало сведений. Учитывая, что о конфликтах не сообщается, установленное договором 1375 г. положение сохранялось все эти годы. Историки подчеркивали зависимое положение Кашина от Москвы [15, с. 165]. А.Е. Пресняков сомневался в том, что кашинский князь сам доставлял ордынскую дань хану [5, с. 398]. Есть известие об участии Василия Кашинского в Куликовской битве на ответственном участке в засадном полку [16, с. 42]. Историки считаюет его вполне правдоподобным [4, с. 166]. Однако весной 1382 г. князь умер. Никоновская летопись отмечает: «Того же лета преставися князь Василей Михайловичь Кашиньскый и положенъ бысть въ соборней церкви въ Воскресеніи въ своей его отчине, во граде Кашине. месяца Мая въ 6 день» [12, с. 71]. Рогожский летописец тепло пишет о покойном, называя его «благоверным христолюбивым», добавляя, что князя похоронили в его «отчине» и «плакашеся надъ нимъ весь градъ Кашинъ...» [10, стб. 143]. Но кашинский князь умер бездетным (неясно даже, был ли он женат), и его княжество стало выморочным.

С формальной точки зрения прекращение местной линии никак не было регламентировано договором 1375 г. в определении дальнейшей судьбы Кашинского княжества. Донской после смерти своего 
двоюродного племянника Василия Михайловича (в такой же степени родства он приходился и тверскому князю) формально мог помешать реализации наследственных прав Михаила Александровича, занять Кашин. В XIV в. московские князья не раз захватывали владения других князей. И сам Дмитрий Иванович довольно жестко проводил политику по изгнанию нелояльных правителей из отдельных княжеств. Так, своих наследственных уделов лишились галицкие князья, потомки Константина Ярославича [17, с. 418-421]. Но Москва не сделала этого. Вероятно, причин было две. С одной стороны, Кашин был частью Тверского княжества и существующая система наследования предусматривала переход владений ближайшему родичу по мужской линии. Таковым оказался великий князь тверской. Очевидно также, что в Москве не хотели новых конфликтов после многолетнего московско-тверского противостояния и победы в Куликовской битве, хотя это существенно усиливало Тверь и сводило на нет предпринятые Москвой усилия. Тверь представляла собой довольно серьезный политический центр. Михаил Тверской вполне законно считал Кашин отчиной своей линии - потомков Михаила Ярославича Тверского. Таким образом, один из главных планов московской элиты по ослаблению потенциального противника потерпел неудачу. Судя по тому, что судьба выморочного Кашинского княжества не отражена источниками, возвращение под власть Михаила Тверского прошел без эксцессов. После нашествия Тохтамыша у Москвы были куда более сложные проблемы. Михаил Тверской отправил в Кашин своего сына. По крайней мере, в известии о сыне Александре Ордынце сообщается о его смерти в 1389 г. в Кашине [18, стб. 444].

В целом, следут отметить, что удельное тверское Кашинское княжество занимало важное место в московско-тверских отношениях этого времени. На ориентацию кашинских князей оказало влияние и родство с московской династией. Вышеуказанный брак Михаила Кашинского и Василисы Московской заложил возможность взаимодействия Кашина и Москвы. В свою очередь, московские князья установили родственные связи с двумя основными линиями тверской династии - Александровичами и Васильевичами, оказывая поддержку на определенном этапе каждой из них. Благодаря браку Москва укрепила союз с кашинскими князьями в борьбе с Михаилом Тверским - своим главным противником во второй половине 60-х - первой половине 70-х гг. XIV в. Вновь, как и в случае с Юрием Даниловичем, мы видим, что своих единственных дочерей московские князья «жертвовали» в Тверь в политических целях, что не может не говорить об первостепенном значении этих связей.

С потерей Василием Кашинским великокняжеского стола усиливается сепарация Кашина от Твери, его обособление. В период московско-тверского соперничества Кашин колебался между двумя центрами силы, в зависимости от изменения хода противостояния и борьбы придворных группировок. Кашинские князь Михаил Васильевич и Василий Михайлович (II) старались отстоять свою независимость от
Твери в союзе с Москвой, так как собственных ресурсов для противодействия великокняжеской тверской власти у кашинских князей не было.

Договор 1375 г. обеспечил независимость Кашинского княжества от Твери, что стало одним из наиболее существенных результатов поражения Михаила Тверского, но сохранил зависимость от Москвы. Однако угасание родственных Дмитрию Донскому кашинских князей в 1382 г. привело к возвращению этого княжества в домен тверских князей. Москва могла помешать этому, но не стала обострять отношения с давним соперником.

\section{СПИСОК ЛИТЕРАТУРЫ:}

1. Татищев В.Н. История Российская. В 7 томах. Т. V. М.-Л.: Наука, 1965. С. 104.

2. Карамзин Н.М. История государства Российского. В 12 томах. Т. V. М.: Наука, 1992. 480 с.

3. Соловьев С.М. История России с древнейших времен. В 18 книгах. Кн. II. М.: Мысль, 1988. 765 с.

4. Борзаковский В. История Тверского княжества. СПб.: Издание книгопродавца И.Г. Мартынова, 1876. $434 \mathrm{c}$.

5. Пресняков А.Е. Образование Великорусского государства. М.: Богородский Печатник, 1998. 496 с.

6. Клюг Э. Княжество Тверское (1247-1485). Тверь: РИФ («Редакционно-издательская фирма») Лтд., 1994. 432 с.

7. Экземплярский А.В. Великие и удельные князья Северной Руси в татарский период с 1238 по 1505 гг. Т. 2. СПб.: Типография Императорской Академии наук, 1891. 696 с.

8. Baumgarten de N. Des Branches Regnantes de Rurikides du XIII-e au XVI-e siècle // Orientalia Christiana. Roma, 1934. T. XXXV-1. Р. 13, 53.

9. Иноземцев А.Д. Удельные князья Кашинские. Эпизод из политической истории Руси XIV и XV столетий // ЧОИДР. М., 1874. № 4.58 с.

10. Полное собрание русских летописей. Рогожский летописец. T. XV (Выпуск 1). М.: Наука, 1965.

11. Акты социально-экономической истории Северо-Восточной Руси. Т. III. М., 1964. 688 с.

12. Полное собрание русских летописей. Летописный сборник, именуемый Патриаршей или Никоновской летописью. Т. ХІ. М.: Языки русской культуры, 2000. 264 с.

13. Полное собрание русских летописей. Московский летописный свод конца XV века / под ред. М.Н. Тихомирова. Т. 25. М.-Л.: Изд-во Академии наук СССР, 1949. 464 c.

14. Духовные и договорные грамоты великих и удельных князей XIV-XVI вв. М.-Л.: Изд-во Академии наук СССР. 586 с.

15. Борзаковский В.С. История Тверского княжества. СПб.: Издание книгопродавца И.Г. Мартынова, $1876.434 \mathrm{c}$.

16. Карамзин Н.М. История государства Российского. Т. 5. М., 1993. 560 с.

17. Веселовский С.Б. Исследования по истории класса служилых землевладельцев. М.: Наука, 1969. $583 \mathrm{c}$.

18. Полное собрание русских летописей. Тверской сборник. T. XV. М.: Наука, 1965. 


\title{
KASHIN PRINCES IN 60-80S OF THE XIV CENTURY
}

(C) 2017

\author{
Abukov Sergey Navilievich, candidate of historical sciences, \\ senior lecturer of Historiography, Source Studies, Archeology and Methods of History Teaching Department \\ Donetsk National University (Donetsk, Donetsk People's Republic)
}

Abstract. In the following paper the author researches the significance of Kashin as an important centre of the Tver Principality during the reign of Grand prince Vasily Mikhailovich and the confrontation between Moscow and Tver, Kashin unstable position of the princes, caused by the struggle of parties among the local ruling elite, caught between the two centers of power. As a result, the part of the elite continued to focus on Tver, while the other gave preference to Moscow. The latter position prevailed, which led to the refusal of the Prince of Kashin from the treaty with Mikhail and his involvement in the campaign against Tver in 1375. Special attention is paid to the growth of local separatism, the fate of the Kashin Principality under the treaty of 1375, securing its secession from the supreme power of Tver, as well as the short period of its formal independence and the circumstances of its return to Tver in 1382.

The influence of the Kashin princes' kinship ties, especially the marriage of Kashin prince Mikhail Vasilievich and the Moscow princess Vasilisa Semenovna, is also analyzed, the reasons, circumstances and significance of this marriage in the light of Moscow-Tver relations in the 60-80s of the XIV century in the general context of conjugal unions of the two leading principalities of North-Eastern Rus.

Keywords: Vasily Mikhailovich; Mikhail Vasilyevich; Vasily Mikhailovich (II); Mikhail Alexandrovich; Mariya Alexandrovna; Semyon the Proud; Dmitry Donskoy; Kashin; Moscow; Tver; Prince; marriage; kinship; conflict; XIV century.

УДК $9(\mathrm{c}) 16$

$$
\begin{aligned}
& \text { «ТЕРСКИЙ ОСТРОГ, ТЕРСКИЙ РЕДУТ, ТЕРКИ?..» } \\
& \text { (ЕЩЁ РАЗ К ВОПРОСУ О РОЛИ ТЕРСКОГО ГОРОДА } \\
& \text { В ИСТОРИИ СЕВЕРО-ВОСТОЧНОГО КАВКАЗА ХУІ-ХУІ ВЕКОВ) }
\end{aligned}
$$

(C) 2017

Гарунова Нина Нурмагомедовна, доктор исторических наук, профессор кафедры истории России с древнейших времен до конца XIX в. Дагестанский государственный университет (2. Махачкала, Российская Федерация)

Суздальцева Ирина Анатольевна, кандидат исторических наук, доцент кафедры истории России Дагестанский государственный педагогический университет (2. Махачкала, Российская Федерация)

Галимова Лилия Надиповна, доктор исторических наук,

профессор кафедры гуманитарных и социальных дисциплин

Ульяновский институт гражданской авиаџии имени Главного маршала авиаџии Б.П. Бугаева (2. Ульяновск, Российская Федераџия)

Аннотация. В данной статье рассматривается история исчезнувшего русского поселения-крепости, которое относится к периоду XVI-XVIII вв. В более ранних источниках город называли Терским редутом, Терским острогом, иногда встречается более короткое название - Терки. Позднее стали использовать название Терский город, для обозначения города и крепости вблизи устья Терека, недалеко от не существующей ныне речки Тюменки. В современный период это территория левобережья Старого Терека к северо-востоку от города Кизляр Республики Дагестан.

Подвергнуты критике попытки отождествления истории двух крепостей: Трехстенного городка и Терки, а также их роли на начальном этапе в истории формирования русского населения Дагестана. Охарактеризовано влияние процесса переоформления казачества в военно-служивое сословие на историческое развитие областей Северо-Восточного Кавказа. Уделено внимание такому вопросу, как наличие различных версий названия города, по месторасположению которого расходятся мнения исследователей.

Сделан акцент на роли Терского города как южного форпоста российской государственности, проводника ее кавказской политики на Северо-Восточном Кавказе.

Проведен анализ проблемы, позволивший рассмотреть интеграцию провинциальных регионов периферии в систему Российского государства на юге страны, а также проанализировано развитие опорных пунктов по распространению влияния России в XVI-XVII вв.

Ключевые слова: крепость; поселение; Терки; Терский город; Терский острог, казаки; политика; Россия; Северо-Восточный Кавказ; торговля; воевода; купцы; Кремль; граница; слобода; редут; острог; устье Терека; артиллерия; гарнизон; наводнение; торговые ряды; башни; двор; служилые люди; корабль; оружие.

Одним из значимых городов-крепостей низовий Терека был Терский город, который представлял собой весьма сложный социально-культурный организм, сложившийся в специфических геополитиче- ских условиях. Выполняя пограничную службу, он являлся форпостом восточной политики Русского государства, центром дипломатических связей с кавказскими феодальными владетелями, Грузией, Ира- 